\title{
T-Cell Response to Hepatitis B Core Antigen: Identification of Prior Exposure to and Confirmatory Testing for Screening for Anti-HBc
}

\author{
Patricia Araujo, ${ }^{1}$ Roger Y. Dodd, ${ }^{2}$ Flavia Latinni, ${ }^{3}$ Renata Souza, \\ Ricardo Diaz, ${ }^{5}$ and Jose Augusto Barreto ${ }^{6}$ \\ ${ }^{1}$ Infection Diseases Laboratory, Colsan/UNIFESP, Avenida Indianópolis, 1260 Indianópolis, São Paulo, SP, Brazil \\ ${ }^{2}$ American Red Cross, USA \\ ${ }^{3}$ Colsan, Technical and Research Department, Brazil \\ ${ }^{4}$ Colsan, Quality Laboratory, Brazil \\ ${ }^{5}$ Retrovirology Laboratory, UNIFESP, Brazil \\ ${ }^{6}$ Colsan, Associação Beneficente de Coleta de Sangue, Head Colsan, Brazil
}

Correspondence should be addressed to Patricia Araujo; rba.patricia@gmail.com

Received 18 June 2013; Revised 8 September 2013; Accepted 8 September 2013

Academic Editor: Rajarshi Pal

Copyright ( 2013 Patricia Araujo et al. This is an open access article distributed under the Creative Commons Attribution License, which permits unrestricted use, distribution, and reproduction in any medium, provided the original work is properly cited.

\begin{abstract}
Background. During routine donor screening in the blood bank, it is not uncommon to find isolated reactivity for anti-HBc in the absence of detectable HBV DNA in a first donation but absence of reactivity to anti-HBc in subsequent donations, suggesting a false-positive result for anti-HBc. Study Design and Methods. The blood donor population was screened between January 2010 and October 2011. We selected 2,126 donations positive only for anti-HBc from a total of 125,068 donations. During the process, OBI donors were identified, and their $\mathrm{HBcAg}$-specific T-cell response was analyzed and compared to donors with chronic (HBsAg positive) and recovered (anti-HBc only) infection. We analyzed correlations between signal levels (Co/s) in the competitive assay for anti-HBc and HBV DNA detection. Results. In the 21-month study period, 21 blood donors with anti-HBc alone were identified as OBI ( 1 in each 5955 donors). The relevant finding was the observation that anti-HBc only subjects with Co/s $\geq 0.1 \mathrm{did}$ not have either HBcAg-specific T-cells or detectable HBV DNA and OBI subjects presented with $\mathrm{Co} / \mathrm{s} \leq 0.1$ and $\mathrm{HBcAg}$ T-cell response. In the subset of 21 OBI subjects, 9 donors remained positive for HBcAg T-cell response after four collections. In all 9 samples, we observed HBV DNA fluctuation. Conclusion. Our data suggest that HBcAg-specific T-cell response could be used to confirm anti-HBc serological status, distinguishing previous exposure to Hepatitis B virus from anti-HBc false-positive results.
\end{abstract}

\section{Introduction}

Hepatitis B virus (HBV) infection is an important global health problem $[1,2]$ especially in Asia, Africa, Southern Europe, and Latin America [3]. About 2 billion people are infected with HBV worldwide [4-7], among them, 400 million suffer chronic HBV infection [5]. In Brazil, the HBsAg positivity ranges from $1.6 \%$ to $8.5 \%$, corresponding to approximately 3 to 16 million infected individuals [8-13]. The residual HBV risk in screened blood transfusion ranges from $1: 10,700[14]$ to $1: 62,734$ [15] and is markedly higher compared to Europe [16], North America [17, 18], Australia [19], and Japan [20].

Further, the identification of blood donors with occult HBV infection (OBI) individuals negative for Hepatitis B antigen (HBsAg) with detectable circulating HBV DNA has created concern related to the safety of the blood supply $[21,22]$.

Hepatitis B virus continues to offer the greatest risk of transfusion-transmission infection despite HBsAg screening of blood donations. Residual risk of HBV transfusiontransmission results from occult $\mathrm{HBV}$ infection, window 
period donations, and possible escape variants. There is a need to develop cost-effective algorithms using available serological and NAT methods to increase blood safety without compromising the availability of blood.

False-positive results in anti-HBc testing and falsenegative results in NAT methods can hamper the identification of occult $\mathrm{HBV}$ infection. In anti-HBc testing, false-positive result to anti-HBc are attributed to nonspecific reactions associated with competitive anti-HBc enzyme immunoassay, possiblly due to IgA or IgM-related molecules produced from nonspecifically activated HBV-specific B lymphocytes or cross-reactivity with other serum components [22]. In donor testing using NAT pooling methods, the low viral load found in most OBIs may affect blood safety and screening algorithms in which confirmation depends upon DNA detection.

The reasons for low HBV DNA levels in absence of detectable HBsAg in OBI remain undefined, but it is conjectured that both host and viral factors are important in suppressing viral replication and maintaining control of the infection $[5,6,23]$.

T-cell mediated responses contribute to the control of viral replication, protect against reinfection, and may lead to spontaneous resolution of infection in OBI [24]. Patients who successfully clear the virus present a T-cell response to HBsAg, core and polymerase proteins [25, 26]. Additionally, increased HBcAg- and HBeAg-specific T-helper cell responses are also seen in patients with viral clearance [27].

The T-cell response in individuals with an anti-HBc only profile showed a typical protective memory when compared to anti-HBc-negative blood donors that have not been exposed to HBV. Cellular and humoral immune response pressure against $\mathrm{HBV}$ envelope proteins are the principal mechanisms originating OBI [28].

In this context, the aim of this study was to develop algorithms/methods to confirm anti-HBc test results. A new method is proposed: detection of $\mathrm{HBcAg}$-specific T-cell responses.

\section{Materials and Methods}

2.1. Blood Donors Included for Cellular Immunity Assessment. The blood donor population from COLSAN-Associação Beneficente de Coleta de Sangue (São Paulo, Brazil) was tested between January 2010 and October 2011. We selected 2,126 donors found positive only for anti-HBc from a total of 125,068 donations. During the process, OBI donors were identified, and their $\mathrm{HBcAg}$-specific T-cell response was analyzed and compared to donors with chronic (HBsAg positive) and recovered (anti-HBc only) infection. As control subjects, we enrolled 100 healthy blood donors that had no reactivity for $\mathrm{HBV}$ including $\mathrm{HBV} \mathrm{PCR}$, and who were nonreactive for Hepatitis C Virus (HCV), Human Immunodeficiency Virus (HIV), Human T-lymphotropic virus (HTLV), Syphilis, and Chagas Diseases. All subjects gave their informed consent, and the study was approved by the UNIFESP Ethical Committee.
2.2. Detection of Serological HBV Markers. Blood units collected at COLSAN-Associação Beneficente de Coleta de Sangue (São Paulo, Brazil) were screened for the presence of serum anti-HBc and HBsAg using a commercial enzyme linked immune-assay (ELISA) (BioMérieux, France). HBe, anti-HBe, anti-HBs, and Core IgM testing was performed using the ELFA system (BioMéreiux, France). HBsAg was confirmed by neutralization test (BioMérieux, France). All the samples were also screened by ELISA for possible HCV, HTLV, HIV infections, syphilis, and Chagas Diseases (ELISA) (BioMérieux, France). Samples with additional reactivity for any other infection were excluded from this study.

2.3. $H B V$ DNA Detection. Serum samples were stored at $-20^{\circ} \mathrm{C}$ and thawed immediately before use. For detection of HBV DNA, DNA was extracted and subsequently subjected to a commercial test for HBV-DNA (COBAS AmpliPrep/COBAS TaqMan HBV Test, v2.0) with a range from as low as $20 \mathrm{IU} / \mathrm{mL}$ to as high as $1.7 \mathrm{E}+08 \mathrm{IU} / \mathrm{mL}$.

2.4. Peripheral Blood Mononuclear Cells Preparation. Peripheral blood mononuclear cells (PBMCs) were freshly isolated from heparinized blood by Ficoll-Hypaque density gradient centrifugation with Lymphoprep (Axis-Shield, Oslo, Norway) as previously described [23]. Subsequently, cells were resuspended in complete RPMI-1640 Medium (Gibco, Invitrogen, Beijing, China), which contained $10 \%$ heat-inactivated fetal bovine serum (Gibco, Invitrogen, Australia), $2 \mathrm{mM}$ L-glutamine, $100 \mathrm{U} / \mathrm{mL}$ penicillin, and $100 \mu \mathrm{g} / \mathrm{mL}$ streptomycin.

2.5. HBcAg Specific T-Cell-Response. T-cells were cultured at $10^{6}$ cells per $\mathrm{mL}$ in RPMI-1640 (Gibco, Invitrogen, Beijing, China) supplemented with $10 \%$ heat-inactivated human $\mathrm{AB}$ serum, $2 \mathrm{mmol} / \mathrm{L}$ l-glutamine, $100 \mathrm{U} / \mathrm{mL}$ penicillin, and $100 \mu \mathrm{g} / \mathrm{mL}$ streptomycin and incubated overnight at $37^{\circ} \mathrm{C}$ and 5 percent $\mathrm{CO}_{2}$. Recombinant $\mathrm{HBcAg}$ ( $\mathrm{rHBcAg}$ ) expressed in Escherichia coli are based on cloned HBV DNA of HBV genotypes A, B, C, D, and F was purchased from DiaSorin, Saluggia, Italy. Seventeen overlapping 20-mer peptides covering the entire HBV core sequence (amino acids 1 to 183 ) were synthesized with a multiple-peptide synthesizer using standard 9-fluorenylmethoxy carbonyl chemistry (Syro, MultiSynTech, Bochum, Germany). Recombinant-HBcAg (10 $\mu \mathrm{g} / \mathrm{mL})$ was added, and cells were further incubated for 5 days. Control cultures included $2 \mu \mathrm{g} / \mathrm{mL}$ phytohemagglutinin (PHA), medium alone, and recombinant HCV NS5 protein, (American Research Products, Belmont, MA). [3H]-Thymidine (specific activity $5 \mathrm{mCi} / \mathrm{mmol}$ ) was added for the last 20 hours of culture. Results were expressed as counts per minute (cpm) for PHA-stimulated cultures and as stimulation index (SI), for example, the ratio between median cpm in the $\mathrm{HBcAg-}$ containing cultures and median cpm of control HCV NS5containing cultures. The 99th percentile of $\mathrm{HBcAg}$-specific SI in 10 healthy blood donors was 2.01. For practical purposes, HBcAg-specific T-cell response was scored positive when SI $>3$. 
2.6. Enzyme-Linked Immunospot Assay (ELISpot) for Interferon-Gamma (IFN- $\gamma$ ). The antigen used for the human IFN- $\gamma$ ELISpot assays was the same used in HBcAg T-cell response ( $\mathrm{rHBcAg})$. Multiscreen-IP 96-well plates (Millipore, Billerica, MA) were coated overnight at $4^{\circ} \mathrm{C}$ with $10 \mu \mathrm{g} / \mathrm{mL}$ anti-human IFN- $\gamma$ monoclonal antibody (1-DIK; Mabtech, Sweden). Plates were washed seven times with DPBS and blocked with RPMI 1640 supplemented with $10 \%$ fetal bovine serum for 2 hours at room temperature. Freshly isolated or frozen-thawed PBMCs $\left(2.5 \times 10^{5} /\right.$ well $)$ were seeded in duplicates. Plates were incubated for 32 hours at $37^{\circ} \mathrm{C}$ with $5 \% \mathrm{CO}_{2}$. After washing, $50 \mu \mathrm{L}$ of $1 \mu \mathrm{g} / \mathrm{mL}$ biotinylated monoclonal antibody to INF- $\gamma$ (7-B6-1; Mabtech, Sweden) was added to each well and incubated for 2 hours at room temperature; plates were subsequently washed seven times and $50 \mu \mathrm{L}$ per well of $1 \mu \mathrm{g} / \mathrm{mL}$ Streptavidin-Alkaline phosphatase (Mabtech, Sweden) was added, and plates were further incubated for 1 hour at room temperature. Plates were washed seven times, and $100 \mu \mathrm{L}$ per well of BCIP/NBT (diluted by distilled water; Zymed BCIP/NBT SUBSTRATE KIT, Invitrogen, Camarillo, CA) was added. After 10 minutes, the colorimetric reaction was stopped by distilled water and washed three times with distilled water. Plates were air dried, and the ImmunoSpot S4 Macro Analyzer (Cellular Technology Ltd, USA) was used for spot counting. Results were expressed as numbers of spot-forming cells (SFC) per $10^{6}$ PBMCs. The number of specific IFN- $\gamma$-secreting cells was calculated by subtracting the value of the unstimulated control from the value of the stimulated sample. The positive control consisted of PBMCs stimulated with $10 \mu \mathrm{g} / \mathrm{mL}$ of $\mathrm{PHA}$, and the criteria for a positive response for the ex vivo ELISpot assays were more than $5 \mathrm{SFC}$ per well and more than twice the number of SFC than the unstipulated control well. Therefore, in this study, more than 20 SFC per $10^{6}$ PBMCs would be a positive response.

2.7. Statistical Analysis. Comparison of paired data from patients at different times of followup was performed by Wilcoxon's signed-rank test. Data from groups of unrelated subjects were compared by Mann-Whitney $U$ test. Correlation between HBV DNA and HBc-specific SI was assessed by Spearman's $\rho$ test.

\section{Results}

3.1. Serological HBV Screening and HBV DNA Detection. A total of 2,126 of 125,068 donations, (1.7\%) were positive for anti-HBc, and none of them had detectable HBsAg in the serum. Reactivity only HBsAg was found in 125 (0.1\%) donations, and $\mathrm{HBsAg}$ plus anti- $\mathrm{HBc}$ was observed in 563 $(0.45 \%)$ donations. Both HBsAg and anti-HBc were absent in 122,254 (97.75\%). Among 2,126 (HBsAg-/anti-HBc+) only 21 samples had detectable HBV DNA. Among the 125 samples with primary infection ( $\mathrm{HBsAg+/anti-HBc-),} 27$ samples had detectable HBV DNA. Among 563 samples with chronic infection (HBsAg+/anti-HBc+), 438 had detectable HBV DNA (Figure 1). Between January 2010 and July 2010, when HBV DNA screening was performed using minipools of 6 samples, we did not observe positive samples in a total of 12.000 screened samples from blood donors with HBsAg and anti-HBc negative. In the 21-month study period, 21 blood donors with anti- $\mathrm{HBc}$ alone profile were identified as OBI ( 1 in each 5955 donors). In the same period, the number of blood donors with reactivity for $\mathrm{HBsAg}$ and anti-HBc was 113 (1 in each 1106 blood donors).

3.2. Signal Values (Co/s) for Anti-HBc in Competition Assay. Among the group of 2,126 samples with anti-HBc only, test reactivity (represented as $\mathrm{Co} / \mathrm{s}$ ) ranged between 0.008 and 0,975 . The samples were divided in two groups based on a threshold of Co/s $=0.1$ and further tested for HBV DNA. 21 samples had HBV DNA detectable and Co/s $\leq 0.1$ and then was classified as OBI, and 2,105 anti-HBc only segregating into 1,293 anti- $\mathrm{HBc} \mathrm{Co} / \mathrm{s} \geq 0.1$ and $812 \mathrm{Co} / \mathrm{s}<0.1$ (Figure 1).

3.3. HBcAg-Specific T-Cell Response. The specificity of the anti-HBc response in these two groups of anti-HBc only samples was investigated further by analyzing the HBcAg Tcell response through T lymphocyte proliferation and INF- $\gamma$ response to specific and nonspecific stimuli. The proliferative response of peripheral blood lymphocytes to nonspecific (PHA) and specific stimuli (HBV core antigen; HCV NS5 antigen) was analyzed in HBV carriers, OBI, healthy donors, and two groups based on a threshold of $\mathrm{Co} / \mathrm{s} \leq 0.1$ and $\mathrm{Co} / \mathrm{s} \geq 0.1$. The relevant finding was the observation that anti-HBc only subjects with $\mathrm{Co} / \mathrm{s} \geq 0.1(n=1.293) \mathrm{did}$ not have either HBcAg-specific T-cells or detectable HBV DNA in any analyzed samples. These subjects were classified as "false-positives" for anti-HBc, corroborated by the absence of reactivity to anti- $\mathrm{HBc}$ in the subsequent donations. The median signal value obtained in the "false-positive" group was equal to healthy blood donors $(\mathrm{SI}<3,0)$. All anti-HBc only with $\mathrm{Co} / \mathrm{s} \leq 0.1(n=833)$ presented $\mathrm{HBcAg}$-specific T-cell responses; however, 21 out of 833 presented detectable HBV DNA (OBI). The median SI obtained in HBV carriers and the OBI group was 13,6 and 12,2 , respectively. The subjects $(n=812)$ with $\mathrm{Co} / \mathrm{s} \leq 0.1$ and $\mathrm{HBcAg}$ T-cell response and undetectable HBV DNA are classified as spontaneous HBV resolvers. Spontaneous HBV resolvers showed a large peripheral blood mononuclear cell (PBMC) response (SI = $36,2)$ to $\mathrm{HBcAg}$ when compared to $\mathrm{HBV}$ carriers and $\mathrm{OBI}$ $(\mathrm{SI}=12,2)(P<0.001)$ (Figure 2$)$. In the subset of 21 OBI subjects, 9 collected samples viral load was quantified in all donations and fluctuated between $<10$ and $118 \mathrm{IU} / \mathrm{mL}$, whereas in three samples HBV DNA was not detected, but $\mathrm{HBcAg}$ T-cell response remained positive in all the study period (Figure 3).

3.4. Enzyme-Linked Immunospot Assay (ELISpot) for IFN$\gamma$. ELISpot-INF- $\gamma$ assays were positive in $\mathrm{HBc}$ only with $\mathrm{Co} / \mathrm{s} \leq 0.1$, OBI, and positive control. The magnitude of $\mathrm{T}$-cell responses to $\mathrm{HBcAg}$ in $\mathrm{HBc}$ only with $\mathrm{Co} / \mathrm{s} \leq 0.1$ ranged from 1,020 to 1,628 ISCs $/ 10^{6}$ PBMCs, whereas among OBI ranged from 132 to 548 ISCs $/ 10^{6} \mathrm{PBMCs}$, among positive controls from 160 to 582 ISCs $/ 10^{6}$ PBMCs, and among $\mathrm{HBc}$ only $\mathrm{Co} / \mathrm{s}>0.1$ and healthy blood donors from 8 to 


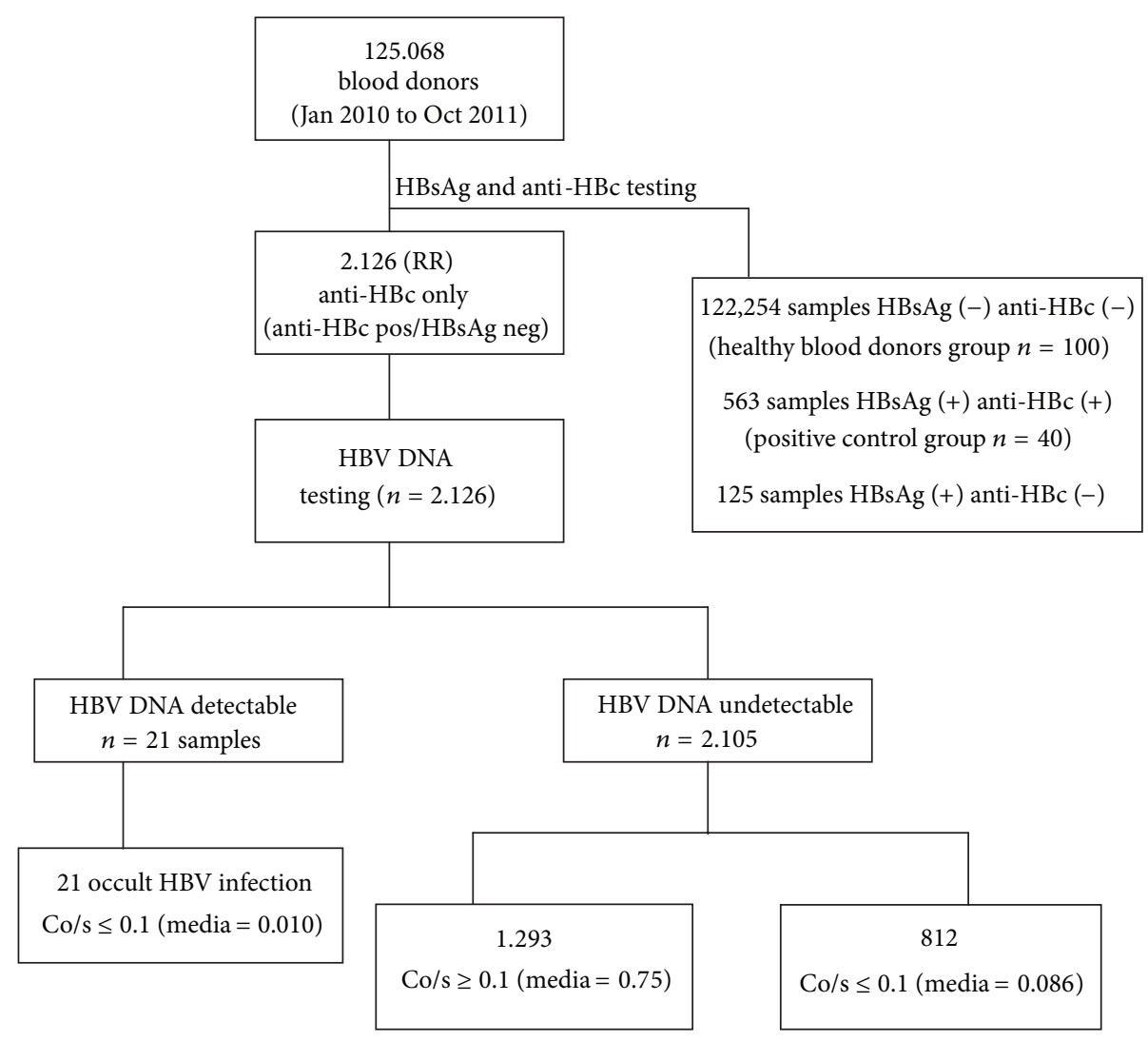

FIgURE 1: Algorithm for classification of studied samples. Co/s = relation between optical density and cutoff in competition assay for anti-HBc (BioMerieux). Among 563 samples with HBsAg (+) anti-HBc (+), 438 samples had HBV DNA detectable. Among 125 samples HBsAg (+) andti-HBc (-), 27 samples had HBV DNA detectable.

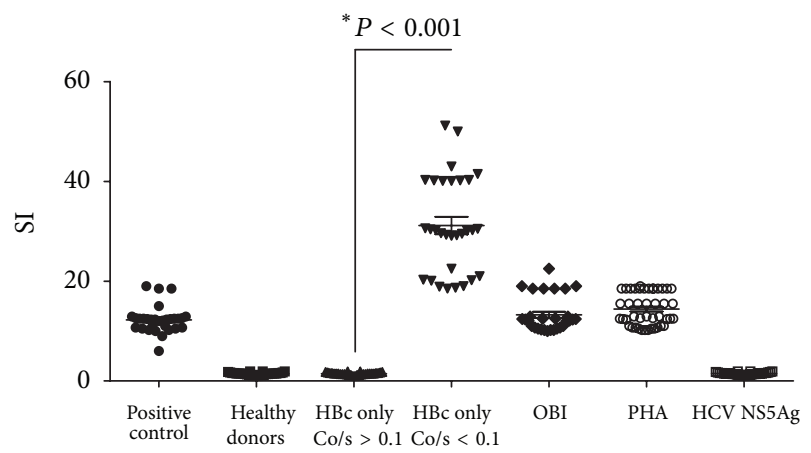

FIGURE 2: The proliferative response of peripheral blood lymphocytes to nonspecific (PHA) and specific stimuli (HBV core antigen; HCV NS5 antigen) in studied groups. SI = index of stimulation. $\mathrm{HBC}$ only with $\mathrm{Co} / \mathrm{s} \geq 0.1$ : absence of T-cell response and HBV DNA classified as false-positive to anti-HBc. $\mathrm{HBc}$ only with $\mathrm{Co} / \mathrm{s} \leq 0.1$ : presence of T-cell response and HBV DNA classified as OBI. HBc only with $\mathrm{Co} / \mathrm{s} \leq 0.1$ : presence of T-cell response and HBV DNA undetectable classified as spontaneous HBV resolvers.

15 ISCs $/ 10^{6}$ PBMCs. The frequency of positive IFN- $\gamma$ ELISpot responses in spontaneous $\mathrm{HBV}$ resolvers indicated a higher chance to have demonstrable $\mathrm{HBV}$-specific T-cell responses than among positive controls $(P<0.001)$ and among OBI $(P<0.001)$ (Figure 4).

3.5. Serological Markers for $H B V$ in $O B I$ and Spontaneous Resolvers Blood Donors. Serological markers of HBV exposure or vaccination (anti-HBs) were observed in 9.1\% (3/40) from primary infection (HBV carriers); $21 \%$ (21/100) of healthy donors; $23,5 \%$ (303/1293) of $\mathrm{HBc}$ only with $\mathrm{Co} / \mathrm{s} \geq$ $0.1 ; 32.4 \%(263 / 812)$ of $\mathrm{HBc}$ only with $\mathrm{Co} / \mathrm{s} \leq 0.1$; and $10,2 \%$ in OBI. Reactivity to IgM anti-core was observed in $2.5 \%(1 / 40)$ and $5.0 \%(2 / 21)$ of $\mathrm{HBV}$ carriers and OBI, respectively. $\mathrm{HBe}$ antigen was observed in all blood donors with $\mathrm{OBI}$ and in $\mathrm{HBV}$ carriers but not in healthy donors and $\mathrm{HBc}$ only. However, $10.5 \%$ (2/21) of OBI and $12.5 \%$ of $(5 / 40)$ $\mathrm{HBV}$ carriers showed anti-HBe-positive. In healthy donors and $\mathrm{HBc}$ only, no reactivity to anti-HBe and Core $\operatorname{IgM}$ was observed (Figure 5).

\section{Discussion}

Hepatitis B virus presents a higher residual risk of transmission by transfusion than hepatitis $\mathrm{C}$ virus ( $\mathrm{HCV}$ ) or human immunodeficiency virus (HIV), especially in countries of South America, like Brazil, where the prevalence of HBsAg in the general population ranges from 2 to $20 \%$ [22]. In this study we found HBV DNA detectable in $21.6 \%$ of blood 


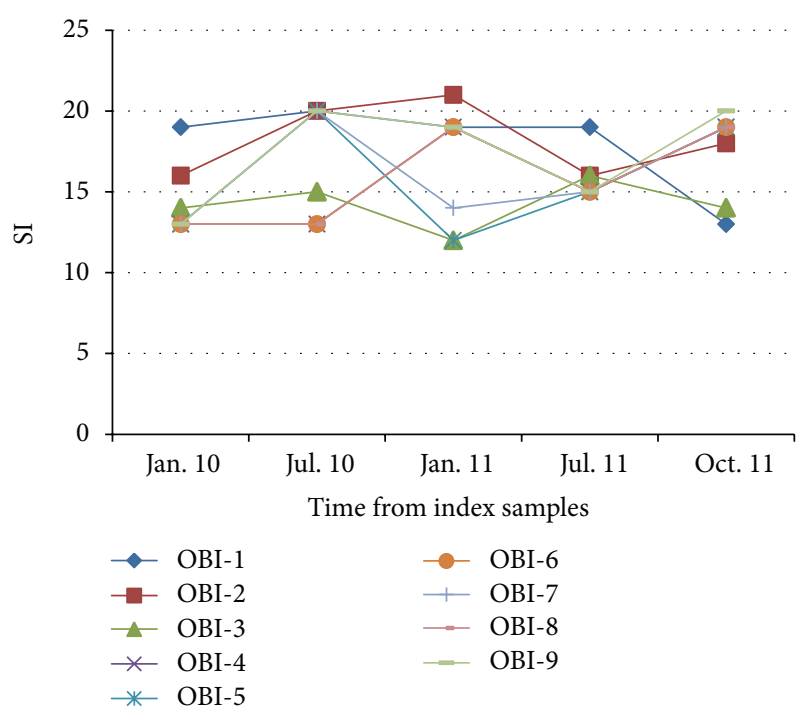

(a)

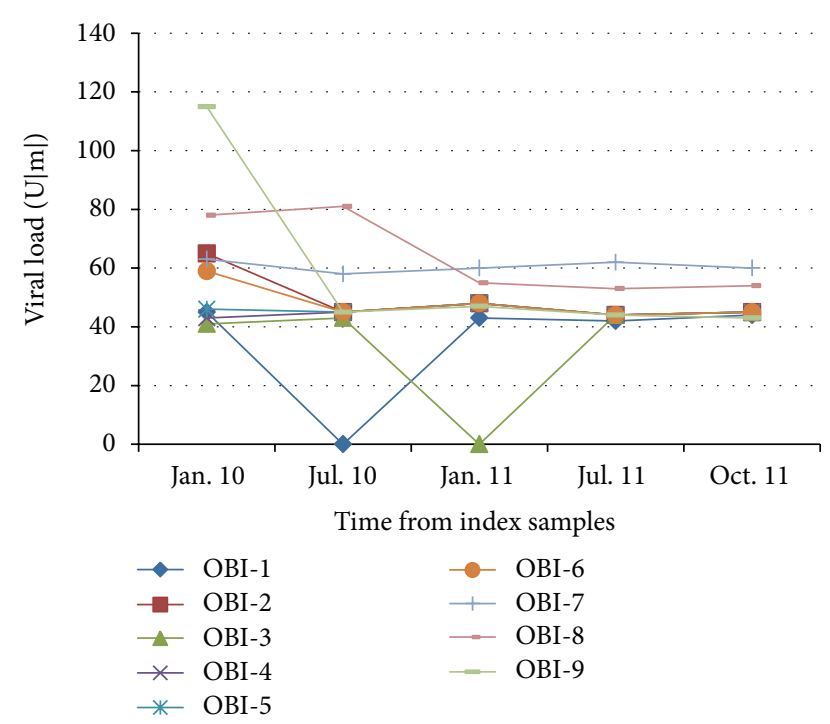

(b)

FIgURE 3: HBcAg T-cell response and HBV load in 9 cases of OBI. OBI-1 to OBI-9 are related to samples with occult HBV infection.

donors with primary infection ( $\mathrm{HBsAg}(+)$ anti-HBc $(-)$ and $77.8 \%$ of chronic blood donors (HBsAg $(+)$ anti-HBc $(+))$. These data are consistent with the observation by several authors about HBV persistence in chronic infection $[29,30]$.

The persistence of HBV DNA was observed like OBI in $0.98 \%$ of the $1.7 \%$ of blood donors which were anti-HBc positive, corroborating results of previous studies [31] that observed $3.3 \%$ OBI subjects into of $5.6 \%$ of blood donors with anti-HBc alone profile. The same assays for detection of HBsAg and anti-HBc were used in both studies, and the detection limit in HBV DNA PCR was similar. In the general blood donor population, the prevalence of OBI in this study was 1 in $5,955(0.017 \%)$, and, in the same period, HBV carrier rate was 1 in 1,106 blood donors. The OBI among blood donors varies from country to country in different parts of

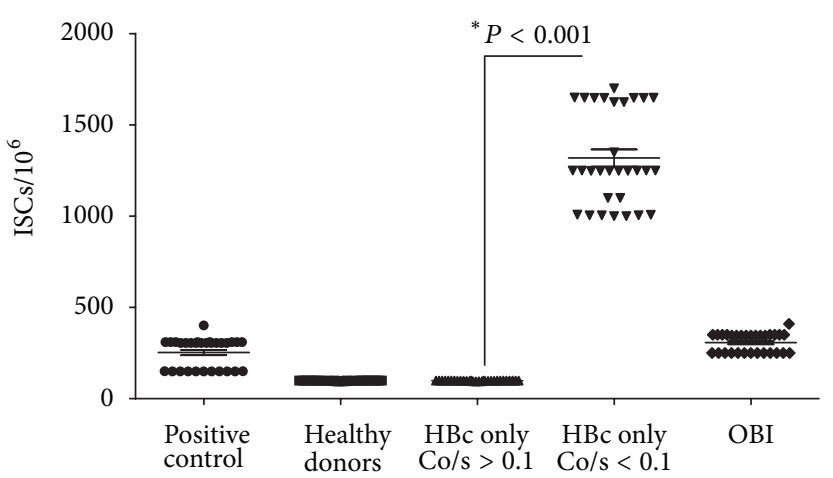

FIGURE 4: ELISpot-INF- $\gamma$ assays in studied groups. ISCs: index spotforming cells index. $\mathrm{HBc}$ only with $\mathrm{Co} / \mathrm{s} \geq 0.1$ : absence of T-cell response and $\mathrm{HBV}$ DNA classified as false-positive to anti-HBc. $\mathrm{HBc}$ only with $\mathrm{Co} / \mathrm{s} \leq 0.1$ : presence of T-cell response and $\mathrm{HBV}$ DNA classified as OBI. $\mathrm{HBc}$ only with $\mathrm{Co} / \mathrm{s} \leq 0.1$ : presence of $\mathrm{T}$ cell response and HBV DNA undetectable classified as spontaneous HBV resolvers.

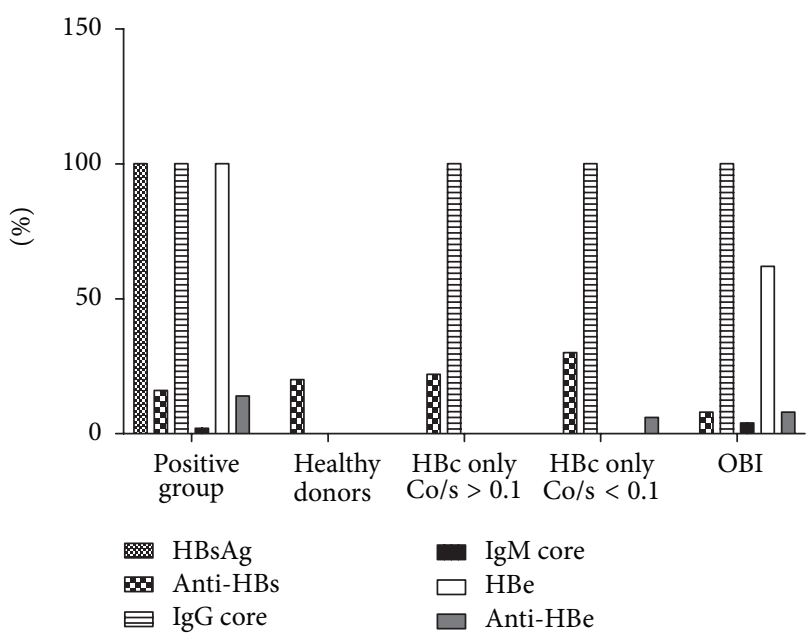

FIGURE 5: Serological markers from HBV in studied groups. HBc only with $\mathrm{Co} / \mathrm{s} \geq 0.1$ : absence of T-cell response and HBV DNA classified as false-positive to anti-HBc. $\mathrm{HBc}$ only with $\mathrm{Co} / \mathrm{s} \leq 0.1$ : presence of T-cell response and HBV DNA classified as OBI. HBc only with $\mathrm{Co} / \mathrm{s} \leq 0.1$ : presence of T-cell response and HBV DNA undetectable classified as spontaneous HBV resolvers.

the world. For example, in the European countries such as Poland, Italy, Spain, and Germany, the OBI prevalence rates of $0.006 \%, 0.22 \%, 0.05 \%$, and $0.0006 \%$, respectively, have been reported by Candotti et al. [32]. In addition, it seems that the prevalence of OBI in blood donors has a regional variance, not only internationally but also nationally. This national discrepancy can be observed in Brazil, where HBV prevalence differs regionally, varying from $2-7 \%$ in the north east to $2-75.6 \%$ in north west [33].

In this context, testing for anti-HBc is important, principally in the detection of cases where HBsAg is negative and HBV DNA detectable (OBI). However, a high frequency of reactivity to anti- $\mathrm{HBc}$ is observed in Brazil ranging from $1.0 \%$ to $5.0 \%$ in Northeast, Midwest, Southeast, and South of 
Brazil but can reach alarming levels of $75.6 \%$ in the Amazonia region. In this study, we observed a $1.7 \%$ of frequency of reactivity to anti-HBc in the absence of $\mathrm{HBsAg}$, according with frequency found in Southeast of Brazil. However, the presence of HBV DNA observed was low representing only $0.98 \%$ of the $1.7 \%$ of anti-HBc only blood donors. These data raise the question "What is the meaning of anti-HBc reactivity in absence of detectable HBV DNA in blood donors?"

In the serological routine in blood bank, it is not uncommon to find isolated reactivity for anti-HBc and HBV DNA undetectable in first donation followed by nonreactive anti$\mathrm{HBc}$ results in the next donation, suggesting that the initial result was false-positive.

The determination of the frequency of true anti-HBc only in blood donors is very important to blood safety strategy and to indentify recovered infection, escape mutants, and OBI. Algorithms including multiple successive assays are necessary but not sufficient to identify true reactivity to anti$\mathrm{HBc}$ [34]. To overcome this difficulty, Japanese blood banks have set up an anti-HBc cutoff agglutination title of $\geq 32$ and, below this level, donations are considered noninfectious (presumably false-positive or with undetectable anti-HBs) [35]. Actually Japanese blood bank defers all donors with any reactive result for anti-HBc.

In this study we had relevant findings about the correlation between threshold $(\mathrm{Co} / \mathrm{s})$ values in anti-HBc competition assay and HBV DNA detection. Among anti-HBc only subjects with detectable HBV DNA, all had Co/s $\leq 0,1$. However, among blood donors with $\mathrm{Co} / \mathrm{s}>0.1$, none had detectable HBV DNA. Distinguishing in this group between HBV exposure and false-positive to anti-HBc appears to be defined by the $\mathrm{HBcAg} \mathrm{T}$-cell response. We found that, among the anti-HBc only group with $\mathrm{Co} / \mathrm{s}<0.1$, and in the presence of HBV DNA, all donors had a response for HBcAg T-cell in all subjects that we classified as occult HBV infection. In anti-HBc only $\mathrm{Co} / \mathrm{s}>0.1$ and in the absence of HBV DNA when there was an $\mathrm{HBcAg} \mathrm{T}$-cell response, we classified these individuals as having spontaneous $\mathrm{HBV}$ clearance, and in absence of HBcAg T-cell response we classified them as falsepositive to anti-HBc.

These findings are corroborated by the difference in magnitude of $\mathrm{HBcAg} \mathrm{T}$-cell response between the groups (HBV carriers and healthy groups), OBI subjects with serial collected samples and ELISpot-INF- $\gamma$ data.

We found a large $\mathrm{HBcAg}$ T-cell response for spontaneous HBV clearance, positive controls, and OBI, all subjects with previous HBV exposure when compared healthy group. We observed HBV DNA fluctuation in 9 cases of OBI with serial collected samples; however, the presence of $\mathrm{HBcAg} \mathrm{T}$ cell response was observed in all serially collected samples. In the follow-up of cases of OBI, we observed fluctuation of viral load but the HBcAg T-cell response was always positive. This is very important to the identification of OBI because it eliminates several problems that are due to false results in HBV DNA detection, like viral load, assay sensitivity, fluctuation of viral load, repeat of the HBV DNA detection, and other factors (mutant, variants, mosaic, and quasispecies). In the other 11 remaining OBIs, we observed linear HBV DNA detection in two subsequent donations. These blood donors will be followed for more two donations, and the results will be analyzed.

In transfusion medicine, assays to detect anti-HBc is recommended to detect potentially infectious blood donors as OBI. Current guide lines suggest retesting of these samples by alternative assays. However, current commercial anti-HBc assays often generate divergent results. $\mathrm{HBcAg}$ specific Tcell response showed high sensibility in distinguishing "true positive" for "false-positive" to anti-HBc.

The results observed in $\mathrm{HBcAg}$ - T-cell response corroborate with ELISpot-INF- $\gamma$ data. We observed that spontaneous $\mathrm{HBV}$ resolvers presented higher frequency of positivity in this assay when compared to HBV carrier, healthy donors, anti-HBc false-positive results, and OBI $(P>0.001)$. In addition, the magnitude of $\mathrm{T}$-cell responses to $\mathrm{HBcAg}$ in $\mathrm{HBV}$ spontaneous resolvers was clearly higher when compared to $\mathrm{HBV}$ carriers, healthy donors, anti-HBc false-positive results, and OBI $(P>0.001)$. These data suggest that antibody titers indeed correlated with $\mathrm{HBcAg}$ - T-cell response and ELISpotINF- $\gamma$.

The presence of immune response was found in ELISpotINF- $\gamma$ in spontaneous HBV resolvers, and OBI and HBV carriers are according to findings of Zerbini et al. who reported that the presence of memory $\mathrm{T}$-cell response in anti$\mathrm{HBc}$ positive individuals with $\mathrm{OBI}$ could be important for maintaining viremia under control but persistent [28].

Despite all the evidence pointing to efficiency of $\mathrm{HBcAg}$ $\mathrm{T}$-cell response to confirm anti- $\mathrm{HBc}$ result in the competition assay, the discrepancy of $\mathrm{HBcAg}$ T-cell response in the OBI and positive groups when compared to findings of Zerbini and cols in 2008 and Bes and cols in 2012 was an important point to elucidate. We suggest that the discrepancy between our results and these researchers could be principally due to process of selection of study groups, because if we introduce the group classified for us as false-positive to anti-HBc, the magnitude of $\mathrm{HBcAg}$ T-cell response is equal between OBI and positive control, if it is considered to be the median of stimulation index found in true positive and false-positive to anti-HBc, agreeing with Zerbini and Bes studies.

$\mathrm{HBcAg}$ T-cell response proved to be an important test to eliminate false-positive results for anti-HBc and that could be used in the research and in blood bank routine. In Brazil, the cost of discarding anti-HBc false-positive donation is high, and the cost to use $\mathrm{HBcAg}$ T-cell response in the laboratory that had previous laminar flow cabinet and $\mathrm{CO}_{2}$ incubator is low, five times smaller than the cost of falsepositive donation. We cannot forget the stigma in the donor to receive a result with positive serology and indirect cost for the public health service to conduct additional tests in order to confirm the positive anti-HBc result. The presence of HBcAg T-cell response in the absence of HBV DNA in cases of OBI suggests that $\mathrm{HBcAg} \mathrm{T}$-cell response could be a complementary or in specific cases an alternative to NAT.

Even with detecting other serological markers of hepatitis B like Core IgM, HBeAg, anti-HBe and anti-HBs, the identification of OBI in anti-HBc only is difficult.

Firstly, we investigated the concentration of anti-HBs in $\mathrm{OBI}$, spontaneous $\mathrm{HBV}$ resolvers, and $\mathrm{HBV}$ carrier, and 
we observed that frequency was $10.2 \%, 32,4 \%$, and $9.1 \%$, respectively. Several studies showed that some individuals with OBI or HBV, who have recovered from HBV infection, produce neutralizing anti-HBs. In these same individuals we may observe continuous HBV DNA replication at low levels that are detectable for years in the liver, peripheral blood mononuclear cells or serum [32, 33, 36-39]. The frequency of anti-HBs found in spontaneous HBV resolvers was higher than HBV carriers and OBI probably due to important immunity role of anti-HBs in protection against HBV infection. The presence of anti-HBs in OBI has been reported by many authors with frequency varying from $0.5 \%$ to $15 \%$ still tested positive for serum HBV DNA, through at a very low titer which is in accordance according with our findings in this study.

Another serological marker studied was anti-HBe, an important marker of HBV chronic carriage [5]. We observed in OBI (10.5\%) and HBV carrier (12.9\%) the presence of antiHBe in lower concentration when compared to levels of anti$\mathrm{HBc}$. This data could be explained by the variable proportion of samples with $\mathrm{HBc}$ alone profile, in which anti-HBe is detected. Although, with lower titers of anti-HBe compared to anti-HBc, there comes a point when the former is no longer detectable, leaving the latter as the only serological marker of infection [5]. HBeAg was observed in all blood donors with viremia, including $\mathrm{OBI}$ and $\mathrm{HBV}$ carrier.

IgM anti-HBc is the first antibody detectable in acute HBV infection, which is usually detected within 1 month after appearance of HBsAg. The presence of IgM anti-HBc with high index value usually indicates a recent HBV infection, and this antibody usually disappears within 6 months. However, the index value of IgM anti-HBc may increase to levels usually detectable in acute infection in $10-20 \%$ of chronic hepatitis B patients with acute exacerbation or hepatitis flare that often leads to a misdiagnosis of acute hepatitis B [40]. In our study we observed that the frequency of high index value of IgM anti-HBc was $5.0 \%$ in OBI and $2.5 \%$ in $\mathrm{HBV}$ carrier, suggesting a recent $\mathrm{HBV}$ infection.

Our data suggest that $\mathrm{HBcAg}$-specific T-cell response could be used to confirm anti-HBc serological status distinguish previous exposure to Hepatitis $\mathrm{B}$ virus and anti- $\mathrm{HBc}$ false-positive.

\section{Ethical Approval}

The ethics were approved by the University of São Paulo, SP, Brazil.

\section{Conflict of Interests}

The authors declare that they have no conflict of interests.

\section{Authors' Contribution}

All authors have made a substantial contribution to the information submitted for this publication.

\section{References}

[1] M. Idrees, S. Khan, and S. Riazuddin, "Common genotypes of hepatitis B virus," Journal of the College of Physicians and Surgeons Pakistan, vol. 14, no. 6, pp. 344-347, 2004.

[2] C. Liu, D. Chen, and P. Chen, "Epidemiology of HBV infection in Asian blood donors: emphasis on occult HBV infection and the role of NAT," Journal of Clinical Virology, vol. 36, supplement 1, pp. S33-S44, 2006.

[3] G. Li, W. Li, F. Guo et al., "A novel real-time PCR assay for determination of viral loads in person infected with hepatitis B virus," Journal of Virological Methods, vol. 165, pp. 9-14, 2010.

[4] D. Paraskevis, C. Haida, N. Tassopoulos et al., "Development and assessment of a novel real-time PCR assay for quantitation of HBV DNA," Journal of Virological Methods, vol. 103, no. 2, pp. 201-212, 2002.

[5] J.-P. Allain, "Occult hepatitis B virus infection: implications in transfusion," Vox Sanguinis, vol. 86, no. 2, pp. 83-91, 2004.

[6] G. Raimondo, J. Allain, M. R. Brunetto et al., "Statements from the Taormina expert meeting on occult hepatitis $B$ virus infection," Journal of Hepatology, vol. 49, no. 4, pp. 652-657, 2008.

[7] S. Zou, S. L. Stramer, and R. Y. Dodd, "Donor testing and risk: current prevalence, incidence, and residual risk of transfusiontransmissible agents in US allogeneic donations," Transfusion Medicine Reviews, vol. 26, no. 2, pp. 119-128, 2012.

[8] M. C. J. Mendes-Corrêa, A. A. Barone, N. D. P. Cavalheiro, F. M. Tengano, and C. Guastini, "Prevalence of hepatitis B and C in the sera of patients with HIV infection in São Paulo, Brazil," Revista do Instituto de Medicina Tropical de Sao Paulo, vol. 42, no. 2, pp. 81-85, 2000.

[9] L. H. S. Oliveira, I. R. Silva, B. L. S. Xavier, and S. M. B. Cavalcanti, "Hepatitis B infection among patients attending a sexually transmitted diseases clinic in Rio de Janeiro, Brazil," Memorias do Instituto Oswaldo Cruz, vol. 96, no. 5, pp. 635-640, 2001.

[10] M. R. D. Monteiro, M. M. do Nascimeeto, A. D. Passos, and J. F. Figueiredo, "Soroepidemiological survey of hepatitis B virus among HIV/AIDS patients in Belém, Pará-Brasil," Revista da Sociedade Brasileira de Medicina Tropical, vol. 37, no. 2, pp. 2732, 2004.

[11] C. V. Tovo, D. E. dos Santos, Â. Z. de Mattos, P. R. L. de Almeida, A. A. de Mattos, and B. R. Santos, "Ambulatorial prevalence of hepatitis B and C markers in patients with human immunodeficiency virus infection in a general hospital," Arquivos de Gastroenterologia, vol. 43, no. 2, pp. 73-76, 2006.

[12] A. M. Zago, T. F. Machado, F. L. Cazarim, and A. E. Miranda, "Prevalence and risk factors for chronic hepatitis B in HIV patients attended at a sexually-transmitted disease clinic in Vitoria, Brazil," Brazilian Journal of Infectious Diseases, vol. 11, no. 5, pp. 475-478, 2007.

[13] A. M. P. Filho, C. U. do Nascimento, T. N. Tannouri et al., "Seroprevalence of HBV, HCV and HIV co-infection in selected individuals from state of São Paulo, Brazil," Memorias do Instituto Oswaldo Cruz, vol. 104, no. 7, pp. 960-963, 2009.

[14] C. Maresch, P. J. Schluter, A. D. Wilson, and A. Sleigh, "Residual infectious disease risk in screened blood transfusion from a high-prevalence population: Santa Catarina, Brazil," Transfusion, vol. 48, no. 2, pp. 273-281, 2008.

[15] P. R. B. Araujo, "Estimates of residual pathogen transmission risk in São Paulo," in Proceedings of the Congress Brazilian Hematology and Hemoterapy, Florianópolis, Brazil, 2010. 
[16] C. Niederhauser, P. Schneider, M. Fopp, A. Ruefer, and G. Lévy, "Incidence of viral markers and evaluation of the estimated risk in the Swiss blood donor population from 1996 to 2003," Euro Surveillance, vol. 10, no. 2, pp. 14-16, 2005.

[17] R. Sitnik, Â. Paes, C. P. Mangueira, and J. R. R. Pinho, "A real-time quantitative assay for hepatitis B DNA virus (HBV) developed to detect all HBV genotypes," Revista do Instituto de Medicina Tropical de Sao Paulo, vol. 52, no. 3, pp. 119-124, 2010.

[18] S. Zou, F. Musavi, E. P. Notari, S. L. Stramer, and R. Y. Dodd, "Prevalence, incidence, and residual risk of major blood-borne infections among apheresis collections to the American Red Cross Blood Services, 2004 through 2008," Transfusion, vol. 50, no. 7, pp. 1487-1494, 2010.

[19] C. R. Seed, P. Kiely, and A. J. Keller, "Residual risk of transfusion transmitted human immunodeficiency virus, hepatitis B virus, hepatitis $\mathrm{C}$ virus and human $\mathrm{T}$ lymphotrophic virus," Internal Medicine Journal, vol. 35, no. 10, pp. 592-598, 2005.

[20] H. Otsubo and K. Yamaguchi, "Current risks in blood transfusion in Japan," Japanese Journal of Infectious Diseases, vol. 61, no. 6, pp. 427-433, 2008.

[21] H. Yotsuyanagi, K. Yasuda, K. Moriya et al., "Frequent presence of HBV in the sera of HBsAg-negative, anti-HBc-positive blood donors," Transfusion, vol. 41, no. 9, pp. 1093-1099, 2001.

[22] M. Bes, V. Vargas, M. Piron et al., "T cell responses and viral variability in blood donation candidates with occult hepatitis B infection," Journal of Hepatology, vol. 56, no. 4, pp. 765-774, 2012.

[23] B. Rehermann, P. Fowler, J. Sidney et al., "The cytotoxic T lymphocyte response to multiple hepatitis B virus polymerase epitopes during and after acute viral hepatitis," Journal of Experimental Medicine, vol. 181, no. 3, pp. 1047-1058, 1995.

[24] Y. Liaw and C. Chu, "Hepatitis B virus infection," The Lancet, vol. 373, no. 9663, pp. 582-592, 2009.

[25] A. Penna, M. Artini, A. Cavalli et al., "Long-lasting memory T cell responses following self-limited acute hepatitis B," Journal of Clinical Investigation, vol. 98, no. 5, pp. 1185-1194, 1996.

[26] R. Thimme, S. Wieland, C. Steiger et al., " $\mathrm{CD} 8^{+} \mathrm{T}$ cells mediate viral clearance and disease pathogenesis during acute hepatitis B virus infection," Journal of Virology, vol. 77, no. 1, pp. 68-76, 2003.

[27] C. Ferrari, A. Penna, A. Bertoletti et al., "Cellular immune response to hepatitis B virus-encoded antigens in acute and chronic hepatitis B virus infection," Journal of Immunology, vol. 145, no. 10, pp. 3442-3449, 1990.

[28] A. Zerbini, M. Pilli, C. Boni et al., "The characteristics of the cellmediated immune response identify different profiles of occult hepatitis B virus infection," Gastroenterology, vol. 134, pp. 14701481, 2008.

[29] S. L. Stramer, U. Wend, D. Candotti et al., "Nucleic acid testing to detect HBV infection in blood donors," The New England Journal of Medicine, vol. 364, no. 3, pp. 236-247, 2011.

[30] S. L. Stramer, S. Zou, E. P. Notari et al., "Blood donation screening for hepatitis $B$ virus markers in the era of nucleic acid testing: are all tests of value?” Transfusion, vol. 52, no. 2, pp. 440446, 2012.

[31] C. M. D. Silva, C. Costi, C. Costa et al., "Low rate of occult hepatitis $\mathrm{B}$ virus infection among anti-HBc positive blood donors living in a low prevalence region in Brazil," Journal of Infection, vol. 51, no. 1, pp. 24-29, 2005.

[32] D. Candotti, P. Grabarczyk, P. Ghiazza et al., "Characterization of occult hepatitis B virus from blood donors carrying genotype
A2 or genotype D strains," Journal of Hepatology, vol. 49, no. 4, pp. 537-547, 2008.

[33] D. Kiesslich, N. A. Fraiji, M. A. Crispim et al., "Prevalence of serologic and molecular markers of hepatitis B virus infection among pregnant women in Amazonas State, Brazil," Epidemiologia e Services de Saúde, vol. 12, no. 3, pp. 155-164, 2003.

[34] S. Levicnik-Stezinar, U. Rahne-Potokar, D. Candotti, N. Lelie, and J. Allain, "Anti-HBs positive occult hepatitis B virus carrier blood infectious in two transfusion recipients," Journal of Hepatology, vol. 48, no. 6, pp. 1022-1025, 2008.

[35] J. H. Kao, "Diagnosis of hepatitis B virus infection through serological and virological markers," Expert Review of Gastroenterology and Hepatology, vol. 2, no. 4, pp. 553-562, 2008.

[36] Y.-Y. Zhang, B. G. Hansson, L. S. K. Kuo, A. Widell, and E. Nordenfelt, "Hepatitis B virus DNA in serum and liver is commonly found in Chinese patients with chronic liver disease despite the presence of antibodies to HBsAg," Hepatology, vol. 17, no. 4, pp. 538-544, 1993.

[37] T. I. Michalak, C. Pasquinelli, S. Guilhot, and F. V. Chisari, "Hepatitis B virus persistence after recovery from acute viral hepatitis," Journal of Clinical Investigation, vol. 93, no. 1, pp. 230239, 1994.

[38] B. Rehermann, C. Ferrari, C. Pasquinelli, and F. V. Chisari, "The hepatitis B virus persists for decades after patients' recovery from acute viral hepatitis despite active maintenance of a cytotoxic T-lymphocyte response," Nature Medicine, vol. 2, no. 10, pp. 1104-1108, 1996.

[39] H. Yotsuyanagi, K. Yasuda, S. Iino et al., "Persistent viremia after recovery from self-limited acute hepatitis B," Hepatology, vol. 27, no. 5, pp. 1377-1382, 1998.

[40] N. Yuki, T. Nagaoka, M. Yamashiro et al., "Long-term histologic and virologic outcomes of acute self-limited hepatitis B," Нераtology, vol. 37, no. 5, pp. 1172-1179, 2003. 


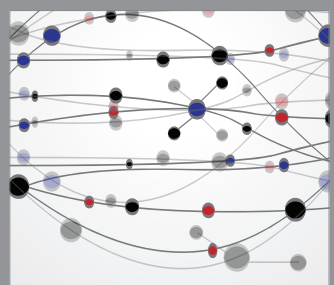

The Scientific World Journal
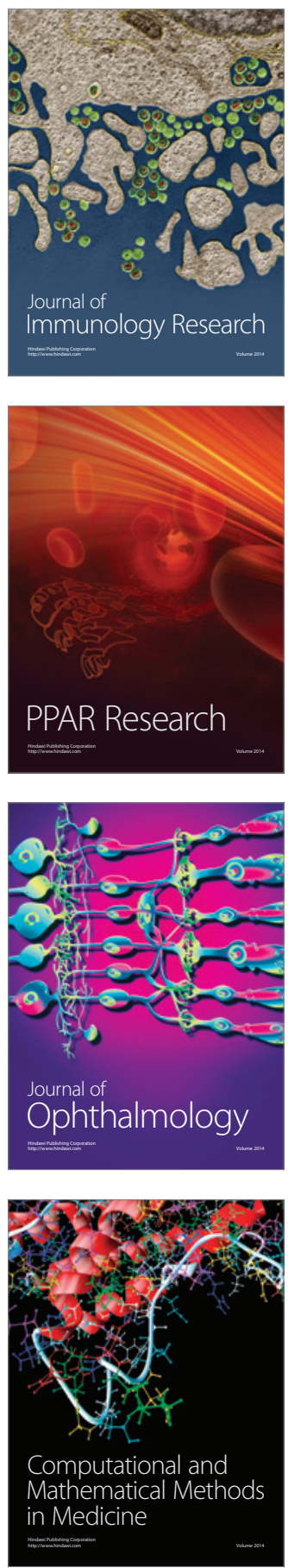

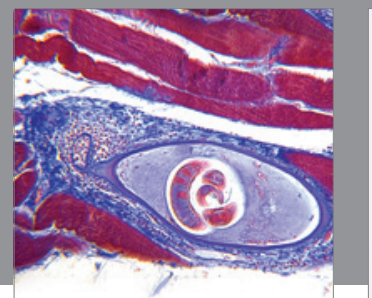

Gastroenterology

Research and Practice
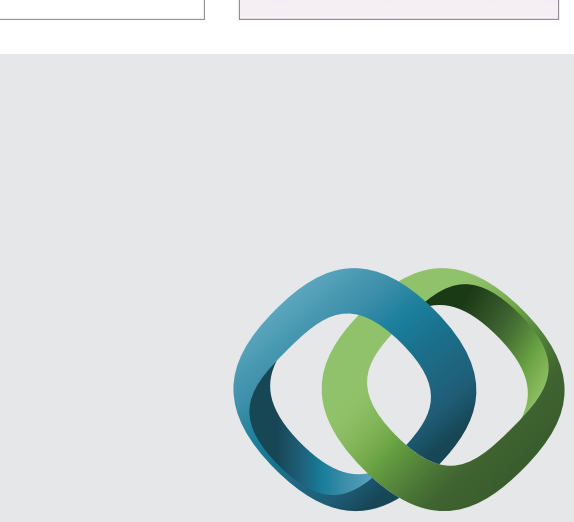

\section{Hindawi}

Submit your manuscripts at

http://www.hindawi.com
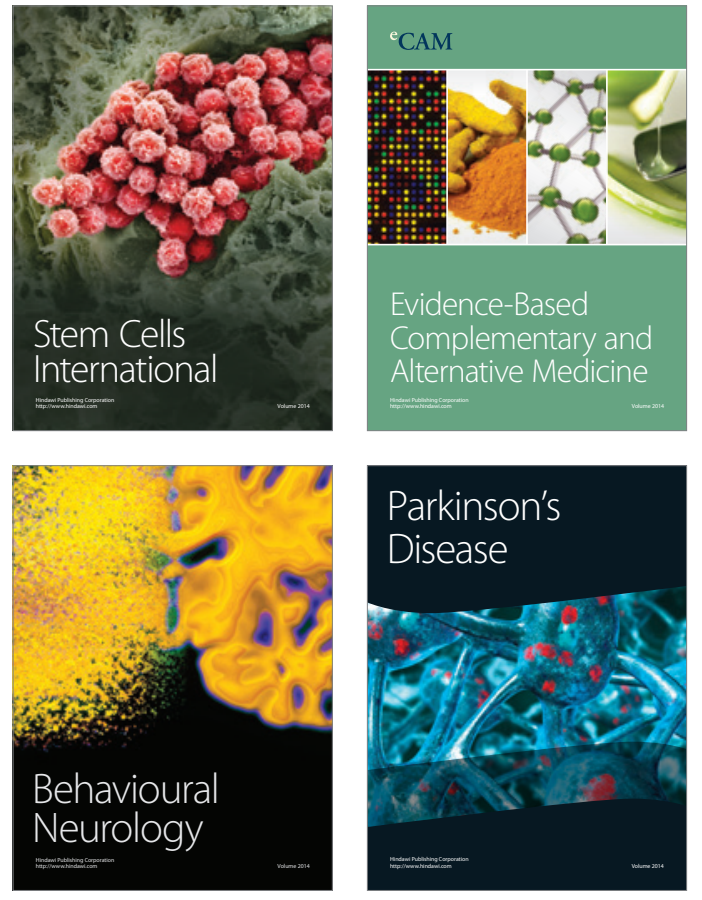
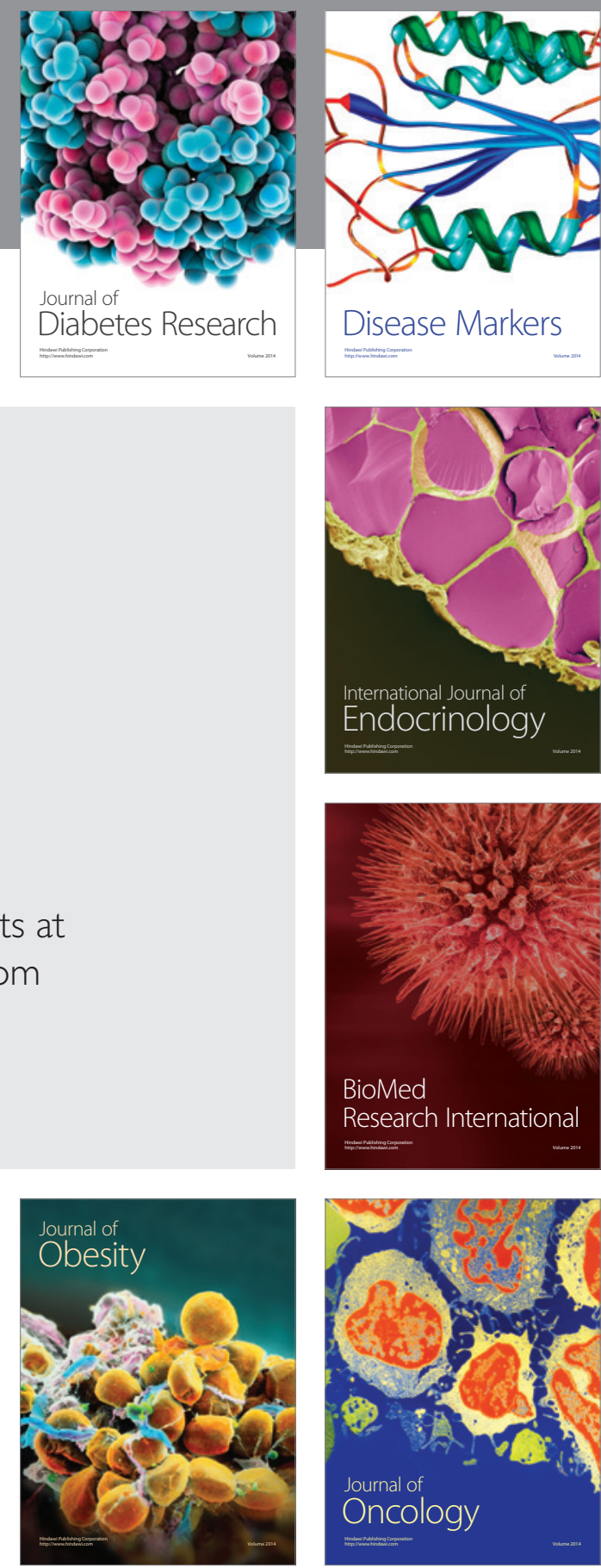

Disease Markers
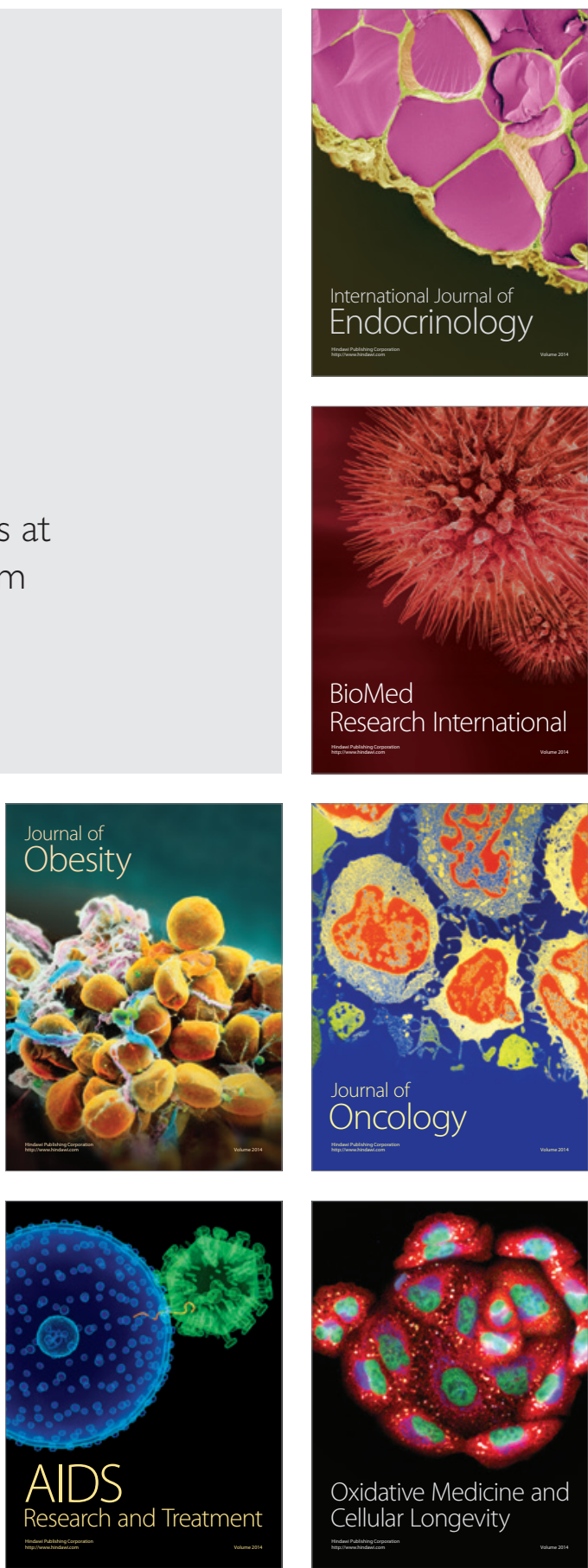